\title{
Physicochemical characteristics and fatty acid profile of meat from lambs with different genotypes and diets
}

\author{
Roberto Germano Costa ${ }^{1}$, Neube Michel dos Santos ${ }^{2}$, Rita de Cássia Ramos do Egypto \\ Queiroga $^{3}$, Wandrick Hauss de Sousa ${ }^{4}$, Marta Suely Madruga ${ }^{5}$, Felipe Queiroga Cartaxo ${ }^{4}$
}

\author{
${ }^{1}$ Universidade Federal da Paraíba, Departamento de Ciência Animal, Bananeiras, PB, Brasil. \\ ${ }^{2}$ Agência Estadual de Vigilância Sanitária, Campina Grande, PB, Brasil. \\ ${ }^{3}$ Universidade Federal da Paraíba, Departamento de Nutrição, João Pessoa, PB, Brasil. \\ ${ }^{4}$ Empresa Estadual de Pesquisa Agropecuária da Paraíba, João Pessoa, PB, Brasil. \\ ${ }^{5}$ Universidade Federal da Paraíba, Departamento de Tecnologia Química e Alimentos, João Pessoa, PB, Brasil.
}

\begin{abstract}
The objective of this study was to evaluate the chemical composition and fatty acid profile of meat from Santa Inês, Dorper $\times$ Santa Inês, and undefined-breed lambs finished in a feedlot system according to two forage:concentrate ratios (50:50 and 20:80) in the diet. Overall, 54 non-castrated animals were used (with an average initial weight of $23 \pm 1.5 \mathrm{~kg}$ at 150 days old) and were slaughtered when they reached $36 \mathrm{~kg}$ of live weight or 63 days of confinement. Diets with high concentrate levels favored meat production with higher protein content. Among the saturated fatty acids, only heptadecanoic $(\mathrm{C} 17: 0)$ and arachidic acids (C20:0) differed among the treatments. The amount of oleic acid detected in the meat ranged from 49.2 to $51.9 \mathrm{~g} / 100 \mathrm{~g}$, making this one the most representative fatty acids. Regardless of the diet and genotype, the unsaturated fatty acid and desirable fatty acid levels in the lamb meat characterize it as of satisfactory quality for the consumer market.
\end{abstract}

Key Words: Dorper, genotype, lipids, meat quality, proximate composition, Santa Inês

\section{Introduction}

Currently, nutrient management practices based on scientific findings, and in accordance with the characteristics of each productive activity, have been used to finish lambs to produce more healthy and nutritious meat (Hummada et al., 2012). Based on inconclusive scientific results (Demirel et al., 2006; Lopes et al., 2014), it could be inferred that higher forage levels in lamb and goat diets during finishing promote greater polyunsaturated fatty acid $\omega 3$ deposition in the muscle tissue due to high levels of linolenic acid (C18:3) in the forage.

Thus, among the pre-slaughter factors that can promote changes in the physicochemical characteristics of lamb meat, genotype is an exceptional parameter that has not been fully evaluated (Martínez-Cerezo et al., 2005). With the increased use of the Santa Ines breed by Brazilian sheep breeders in recent decades and the introduction of the Dorper breed, which is recognized for its outstanding meat production potential, new prospects for developing the sheep industry have emerged in Brazil (Sousa et al., 2008). Terminal crossings between native genotypes and exotic breeds

Received February 5, 2015, and accepted April 15, 2015

Corresponding author: betogermano@hotmail.com

http://dx.doi.org/10.1590/S1806-92902015000700003

Copyright $@ 2015$ Sociedade Brasileira de Zootecnia. This is an Open Access article distributed under the terms of the Creative Commons Attribution Non-Commercial License, which permits unrestricted non-commercial use, distribution, and reproduction in any medium, provided the original work is properly cited. with specific cutting characteristics, such as Dorper from Africa, have been suggested as important alternatives for increasing production as well as improving the productive characteristics, carcass quality, and meat quality of native cattle (Silva Sobrinho et al., 2005).

Additional information on the quality of meat of Santa Inês lambs, crossbred lambs from terminal crossings, such as Dorper $\times$ Santa Inês, and animals with undefined breeds (UDB) can help expand the demand for this product through the development of appropriate marketing strategies. Therefore, to provide information on adequate diets for finishing meat-producing sheep in Northeastern Brazil, this study evaluated the effect of two forage:concentrate ratios (50:50 and 20:80) in the diets of Santa Inês, Santa Inês $\times$ Dorper, and UDB lambs finished in a feedlot system by examining certain parameters, such as $\mathrm{pH}$, carcass temperature, proximate composition, and the fatty acid profile of their meat.

\section{Material and Methods}

This study was performed in accordance with ethical standards and approved by the Ethics Research and Biosafety Committee of Universidade Federal da Paraíba.

Fifty-four non-castrated lambs were used, including 18 Santa Inês, $18 \mathrm{~F}_{1}$ Dorper $\times$ Santa Inês, and 18 UDB. The lambs had an initial average weight of $23 \pm 1.5 \mathrm{~kg}$ and were, on average, 150 days old; they were individually distributed 
in cages measuring $0.80 \times 1.20 \mathrm{~m}$ and were provided food and water. The adaptation period consisted of 14 days, and the lambs were weighted weekly to monitor body development. The animals were initially vaccinated against clostridial and worms through subcutaneous injection of $1 \%$ ivermectin.

The diets (Table 1) were isoproteic and provided twice a day $(08.00 \mathrm{~h}$ and $17.00 \mathrm{~h})$; the diets were formulated to meet the crude protein and metabolizable energy requirements that allowed the animal to gain $250 \mathrm{~g} /$ day in accordance with the recommendations in the NRC (2007). A $50 \mathrm{~g} / \mathrm{kg}$ dry matter average intake relative to body weight was established and adjusted according to the leftovers from the previous day.

The diets consisted of two forage:concentrate ratios, 50:50 and 20:80, and the chemical composition of the ingredients used in the experimental diets was determined using the methods described in AOAC (2000) and Van Soest et al. (1991) (Table 2).

Table 1 - Ingredients and chemical composition of the diets according to the forage:concentrate ratio

\begin{tabular}{lcc}
\hline & \multicolumn{2}{c}{ Forage:concentrate ratio } \\
\cline { 2 - 3 } Ingredient $(\mathrm{g} / \mathrm{kg})$ & $20: 80$ & $50: 50$ \\
\hline Tifton hay & 212 & 500 \\
Ground corn & 543 & 128 \\
Soybean meal & 208 & 168 \\
Wheat bran & - & 190 \\
Soybean oil & 20 & - \\
Mineral salt ${ }^{1}$ & 5 & 5 \\
Limestone & 12 & 9 \\
Chemical composition & & \\
Dry matter (g/kg DM) & 805 & 888 \\
Crude protein (g/kg DM) & 170 & 170 \\
Metabolizable energy (Mcal/kg DM) & 2.9 & 2.4 \\
Total digestible nutrients $(\mathrm{g} / \mathrm{kg} \mathrm{DM})^{2}$ & 802 & 664 \\
Neutral detergent fiber (g/kg DM) & 273 & 520.5 \\
Calcium (g/kg DM) & 7.1 & 7.3 \\
Phosphorus (g/kg DM) & 3.2 & 4.3 \\
Ether extract (g/kg DM) & 48.9 & 22.9 \\
Non-fibrous carbohydrates (g/kg DM) & 482 & 247.4 \\
\hline
\end{tabular}

${ }^{1}$ Mineral salt composition per kilogram: $147 \mathrm{~g} \mathrm{Na} ; 120 \mathrm{~g} \mathrm{Ca} ; 87 \mathrm{~g} \mathrm{P} ; 18 \mathrm{~g} \mathrm{~S} ; 3,800 \mathrm{mg}$ $\mathrm{Zn} ; 3,500 \mathrm{mg} \mathrm{Fe} ; 1,300 \mathrm{mg} \mathrm{Mn} ; 870 \mathrm{mg} \mathrm{Fl} ; 590 \mathrm{mg} \mathrm{Cu} ; 300 \mathrm{mg} \mathrm{Mo} ; 80 \mathrm{mg} \mathrm{I}$; $40 \mathrm{mg} \mathrm{Co} ; 20 \mathrm{mg} \mathrm{Cr} ; 15 \mathrm{mg} \mathrm{Se} ; 250 \mathrm{mg}$ vit. A (IU); $100 \mathrm{mg}$ vit. D (IU); $500 \mathrm{mg}$ vit. E (IU).

${ }^{2} \mathrm{TDN}=\mathrm{DCP}+2.25 \times \mathrm{DEE}+\mathrm{DNFC}+\mathrm{DNDFap}$.
The non-fibrous carbohydrates (NFC) were determined using the equation proposed by Weiss (1999): $\% \mathrm{NFC}=100$ $-(\% \mathrm{DNDFap}+\% \mathrm{CP}+\% \mathrm{EE}+\%$ ash $)$, in which DNDFap, $\mathrm{CP}$ and $\mathrm{EE}$ are, respectively, digestible neutral detergent fiber (free of ash and protein), crude protein and ether extract. The Metabolizable energy (ME) values of the diets were calculated considering that $1 \mathrm{~kg}$ of total digestible nutrient (TDN) equals 4.409 Mcal of DE, and $1 \mathrm{Mcal}$ of DE equals 0.82 Mcal of ME (Harris, 1970). The TDN levels were obtained from an equation proposed by Weiss (1999): $\mathrm{TDN}=\mathrm{DCP}+2.25 \times \mathrm{DEE}+\mathrm{DNFC}+\mathrm{DNDFap}$, in which DCP, DEE, DNFC, and DNDFap are, respectively, the digestible crude protein, digestible ether extract, digestible non-fiber carbohydrates and digestible neutral detergent fiber (free of ash and protein).

The lambs were slaughtered when they reached $36 \pm 2.4 \mathrm{~kg}$ live weight or 63 days of confinement, and their weight was evaluated after an 18-h solid fasting period. The slaughter was performed in accordance with the standards of the Rules of Industrial and Sanitary Inspection of Animal Products (Brasil, 1997); the carcasses were hung by the tendons on appropriate hooks, which were spaced $17 \mathrm{~cm}$ from one another, and cooled in a cold storage chamber at $1 \pm 4{ }^{\circ} \mathrm{C}$ for $24 \mathrm{~h}$. The carcasses were wrapped in transparent plastic bags to reduce the loss of surface moisture during the cooling process.

After the slaughter, the carcasses were stored in a cold chamber to determine the $\mathrm{pH}$ and temperature (T) using a digital potentiometer with a penetration electrode (DIGIMED, model pH 300M, São Paulo, Brazil) introduced into 2-4 cm deep cuts, made using a scalpel, in the longissimus lumborum muscle between the 4th and 5th lumbar vertebrae, avoiding contact with fat and connective tissues (where possible). The carcasses were measured immediately after slaughter (initial $\mathrm{PH}_{0}$ and $\mathrm{T}_{0}$ ), after 45 min $\left(\mathrm{pH}_{45}\right.$ and $\left.\mathrm{T}_{45}\right)$ and after $24 \mathrm{~h}\left(\mathrm{pH}_{24}\right.$ and $\left.\mathrm{T}_{24}\right)$ using the methodology described by Cezar and Sousa (2007). After the carcasses cooled, the longissimus lumborum muscles were removed, vacuum-packaged and stored in a cold chamber at $-18 \pm 1{ }^{\circ} \mathrm{C}$ for future laboratory analyses. The

Table 2 - Chemical composition of the diet ingredients (g/kg DM)

\begin{tabular}{lcccccccc}
\hline Ingredient & DM & CP & EE & ME & TDN & NDF & NFC & MM \\
\hline Tifton hay & 889.6 & 89.6 & 16.3 & 2.01 & 555.9 & 787.8 & 74.4 & 67.2 \\
Soybean meal & 886.1 & 487.8 & 29.5 & 2.95 & 815.9 & 146.2 & 300.0 & 63.2 \\
Ground corn & 876.4 & 91.1 & 40.7 & 3.15 & 871.2 & 139.8 & 744.7 & 15.5 \\
Wheat bran & 890.0 & 166.3 & 35.3 & 2.61 & 721.9 & 443.0 & 339.3 & 55.8 \\
Soybean oil & 995.5 & - & 990.4 & 7.48 & 2072.7 & - & - & - \\
Limestone & 990.0 & - & - & - & - & - & - \\
Mineral salt & 990.0 & - & - & - & - & - & - \\
\hline
\end{tabular}

DM - dry matter; CP - crude protein; EE - ether extract; ME - metabolizable energy; TDN - total digestible nutrients; NDF - neutral detergent fiber; NFC - non-fibrous carbohydrates; $\mathrm{MM}$ - mineral matter.

${ }^{1} \mathrm{Mcal} / \mathrm{kg}$ DM. 
carcass fat percentage was indirectly estimated through a leg dissection (Purchas et al., 1991).

To perform the proximate composition analysis, the longissimus lumborum muscle samples were thawed at $4 \pm 1{ }^{\circ} \mathrm{C}$ for $24 \mathrm{~h}$ and ground in an $\mathrm{Arno}^{\circ}$ domestic blender for an average of $5 \mathrm{~min}$ until the meat reached complete material homogeneity; subsequently, the moisture, ash, and protein were measured using the methodology described in AOAC (2000; methods 985.41, 920153 and 928.08, respectively), and the total lipids were measured using the methodology described by Folch et al. (1957).

The fatty acid profile was determined after extracting the total lipids and performing the esterification and methylation processes using the methodology described by Hartman \& Lago (1973). Fatty acid methyl esters were separated and quantified on a gas chromatograph (GCMASTER, Shimadzu, Brazil) and a fused silica capillary column (MEGABORE, J \& W Scientific, USA) with a polyethylene glycol stationary phase; the column was $30 \mathrm{~m}$ long, with a $0.53 \mathrm{~mm}$ internal diameter and $0.25 \mathrm{~mm}$ film thickness. Hydrogen was the carrier gas, with a flow rate of $5 \mathrm{~mL} / \mathrm{min}$. One-microliter methyl ester aliquots were introduced in a split/splitless type injector at $200{ }^{\circ} \mathrm{C}$. The following chromatographic conditions were applied: initial column temperature of $80{ }^{\circ} \mathrm{C}$ for $3 \mathrm{~min}$, followed by an increase to $175^{\circ} \mathrm{C}$ at a rate of $10{ }^{\circ} \mathrm{C} / \mathrm{min}$ in the first ramp, where the temperature remained for $10 \mathrm{~min}$. The column temperature was increased again to $200{ }^{\circ} \mathrm{C}$ at a rate of $10{ }^{\circ} \mathrm{C} / \mathrm{min}$, where the temperature remained for five minutes, resulting in $30 \mathrm{~min}$ of analysis. The flame ionization detector temperature was maintained at $220{ }^{\circ} \mathrm{C}$. The chromatograms of the retention time and fatty acid methyl esters percentage area data were recorded using the PeakSimple software (ARI Instruments - USA). The fatty acids were identified and quantified in accordance with European Standard EN 14103:2001.

The experimental design was a completely randomized design with a $3 \times 2$ factorial arrangment (three genotypes and two forage:concentrate ratios), with nine replicates per treatment. The following statistical model was used: $Y_{i j k}=\mu+\alpha_{i}+\beta_{j}+\alpha \beta_{i j}+\varepsilon_{i j k}$, in which $Y_{i j k}$ is the value observed for the dependent variable studied; $\mu$ is the overall mean; $\alpha_{i}$ is the effect of genotype $i ; \beta_{j}$ is the effect of diet $j$; $\alpha \beta_{i j}$ is the genotype $\times$ diet interaction; and $\varepsilon_{i j k}$ is the random error associated with each observation. The means were compared using Tukey's test with a probability level of 0.05 , using the GLM procedure from the SAS (Statistical Analysis System, version 8.1) package.

\section{Results}

The genotype was not characterized as a parameter that influenced the final weight, average daily weight gain, and confinement period (Table 3); however, these variables were influenced by diet. The diet with the 20:80 forage: concentrate ratio provided more satisfactory production rates (i.e., greater weight gain and shorter confinement period). The diets containing high concentrate levels and, therefore, higher caloric content, provided greater fat accumulation in the carcasses $(\mathrm{P}<0.05)$.

The $\mathrm{pH}$ values were within the normal range (Table 4), which is consistent with data from Silva Sobrinho et al., (2005), who showed no cases of muscle glycogen storage depletion before slaughter; therefore, the genotypes studied showed reduced susceptibility to normal slaughter stress, which was corroborated by Sañudo et al. (1997). The initial carcass temperature of the lambs fed the diets containing $200 \mathrm{~g} / \mathrm{kg}$ of forage $\left(38.6{ }^{\circ} \mathrm{C}\right)$ was lower than that of lambs fed diets supplemented with $500 \mathrm{~g} / \mathrm{kg}$ of forage $\left(39.4{ }^{\circ} \mathrm{C}\right)$.

The moisture and lipid levels (Table 5) confirm the inverse relationship between these parameters. Carcasses with higher lipid concentrations usually have lower moisture levels. Among the genotypes studied, Santa Inês was characterized by lower lipid levels in the meat $(2.2 \mathrm{~g} / 100 \mathrm{~g})$. Concentrate-rich diets $(20: 80)$ favored protein synthesis by

Table 3 - Mean values for weight variables, confinement period (CP) and fat content in the carcasses of Santa Inês (SI), Dorper $\times$ Santa Inês $(\mathrm{DP} \times \mathrm{SI})$, and undefined breed (UDB) lambs according to the forage:concentrate ratio in the diet

\begin{tabular}{|c|c|c|c|c|c|c|c|c|}
\hline \multirow[b]{2}{*}{ Variable } & \multicolumn{2}{|c|}{ Forage:concentrate ratio (D) } & \multicolumn{3}{|c|}{ Genotype (G) } & \multicolumn{3}{|c|}{ Significance } \\
\hline & $20: 80$ & $50: 50$ & SI & $\mathrm{DP} \times \mathrm{SI}$ & UDB & $\mathrm{D}$ & G & $\mathrm{D} \times \mathrm{G}$ \\
\hline IW (kg) & $22.4 \pm 1.6$ & $22.9 \pm 1.5$ & $23.3 \pm 1.8$ & $22.7 \pm 1.1$ & $22.5 \pm 1.6$ & 0.184 & 0.359 & 0.255 \\
\hline $\mathrm{FW}(\mathrm{kg})$ & $36.6 \pm 2.6 \mathrm{a}$ & $35.3 \pm 2.2 b$ & $36.6 \pm 2.5$ & $35.5 \pm 2.3$ & $35.7 \pm 2.6$ & 0.027 & 0.167 & 0.158 \\
\hline TWG & $17.3 \pm 2.7 \mathrm{a}$ & $13.8 \pm 1.7 \mathrm{~b}$ & $15.1 \pm 2.7$ & $15.3 \pm 2.7$ & $16.2 \pm 2.9$ & 0.044 & 0.256 & 0.353 \\
\hline ADWG (g) & $258.2 \pm 58.9 \mathrm{a}$ & $204.2 \pm 44.8 b$ & $240.6 \pm 61.4$ & $223.0 \pm 53.7$ & $229.9 \pm 62.1$ & 0.038 & 0.159 & 0.262 \\
\hline CP (days) & $56.3 \pm 7.1 \mathrm{a}$ & $61.4 \pm 4.4 \mathrm{~b}$ & $56.8 \pm 7.1$ & $60.7 \pm 5.3$ & $59.1 \pm 6.4$ & 0.019 & 0.364 & 0.269 \\
\hline Fat $(g / 100 \mathrm{~g})$ & $8.4 \pm 2.9 \mathrm{a}$ & $6.5 \pm 2.3 b$ & $5.3 \pm 1.6 \mathrm{c}$ & $9.8 \pm 2.9 \mathrm{a}$ & $7.2 \pm 1.8 \mathrm{~b}$ & 0.024 & 0.039 & 0.133 \\
\hline
\end{tabular}

a, b, c - means followed by different letters are significantly different by Tukey's test

IW - initial weight; FW - final weight; TWG - total weight gain; ADWG - average daily weight gain. 
the animal, as observed in the Santa Inês and UDB lamb meat. No difference $(\mathrm{P}>0.05)$ was observed between the protein levels in the meat from Dorper $\times$ Santa Inês lambs; however, higher absolute levels were observed in the meat from animals fed a lower forage percentage, which yielded a significant interaction between the factors for this genotype.
With respect to the fatty acid profile (Table 6), myristic (C14:0) and palmitic acids (C16:0) are considered hypercholesterolemic (Bonanome and Grundy, 1988) and favor the formation of cardiovascular diseases (Chiara et al., 2002). The concentrations of these fatty acids ranged from 0.70 to $2.90 \mathrm{~g} / 100 \mathrm{~g}$ and 14.34 to $16.06 \mathrm{~g} / 100 \mathrm{~g}$, respectively. French et al. (2003) reported that myristic acid (C14:0)

Table 4 - Hydrogen ion potential $(\mathrm{pH})$ and carcass temperatures $(\mathrm{T})$ of Santa Inês $(\mathrm{SI})$, Dorper $\times$ Santa Inês $(\mathrm{DP} \times \mathrm{SI})$, and undefined breed (UDB) lambs according to the forage:concentrate ratio in the diet

\begin{tabular}{|c|c|c|c|c|c|c|c|c|}
\hline \multirow[b]{2}{*}{ Variable } & \multicolumn{2}{|c|}{ Forage:concentrate ratio (D) } & \multicolumn{3}{|c|}{ Genotype (G) } & \multicolumn{3}{|c|}{ Significance } \\
\hline & $20: 80$ & $50: 50$ & SI & $\mathrm{DP} \times \mathrm{SI}$ & UDB & $\mathrm{D}$ & G & $\mathrm{D} \times \mathrm{G}$ \\
\hline $\mathrm{pH}_{0 \mathrm{~h}}$ & $6.6 \pm 0.3 b$ & $6.8 \pm 0.2 \mathrm{a}$ & $6.6 \pm 0.3$ & $6.8 \pm 0.1$ & $6.7 \pm 0.2$ & 0.042 & 0.259 & 0.168 \\
\hline $\mathrm{pH}_{45 \min }$ & $6.5 \pm 0.2$ & $6.5 \pm 0.2$ & $6.4 \pm 0.2$ & $6.5 \pm 0.1$ & $6.6 \pm 0.2$ & 0.474 & 0.354 & 0.457 \\
\hline $\mathrm{pH}_{24 \mathrm{~h}}$ & $5.5 \pm 0.1$ & $5.5 \pm 0.1$ & $5.5 \pm 0.1$ & $5.5 \pm 0.1$ & $5.5 \pm 0.1$ & 0.169 & 0.356 & 0.262 \\
\hline $\mathrm{T}_{0 \mathrm{~h}}\left({ }^{\circ} \mathrm{C}\right)$ & $38.6 \pm 1.4 \mathrm{~b}$ & $39.4 \pm 0.6 \mathrm{a}$ & $38.7 \pm 0.8$ & $39.3 \pm 0.9$ & $39.0 \pm 1.5$ & 0.001 & 0.156 & 0.272 \\
\hline $\mathrm{T}_{45 \min }\left({ }^{\circ} \mathrm{C}\right)$ & $34.6 \pm 2.0$ & $35.2 \pm 1.2$ & $33.7 \pm 1.8 \mathrm{~b}$ & $35.8 \pm 1.2 \mathrm{a}$ & $35.2 \pm 1.1 \mathrm{a}$ & 0.153 & 0.003 & 0.166 \\
\hline $\mathrm{T}_{24 \mathrm{~h}}^{45 \min }\left({ }^{\circ} \mathrm{C}\right)$ & $5.94 \pm 1.1 \mathrm{a}$ & $5.28 \pm 0.4 \mathrm{~b}$ & $5.85 \pm 1.1$ & $5.57 \pm 0.9$ & $5.41 \pm 0.6$ & 0.004 & 0.263 & 0.259 \\
\hline
\end{tabular}

a, b - means followed by different letters are significantly different by Tukey's test.

Table 5 - Chemical composition of the meat from Santa Inês (SI), Dorper $\times$ Santa Inês $(\mathrm{DP} \times \mathrm{SI})$, and undefined breed (UDB) lambs according to the forage:concentrate ratio in the diet

\begin{tabular}{|c|c|c|c|c|c|c|c|c|c|}
\hline \multirow[b]{2}{*}{ Variable $(g / 100 g)$} & \multicolumn{2}{|c|}{ SI } & \multicolumn{2}{|c|}{$\mathrm{DP} \times \mathrm{SI}$} & \multicolumn{2}{|c|}{ UDB } & \multicolumn{3}{|c|}{ Significance } \\
\hline & $20: 80$ & $50: 50$ & $20: 80$ & $50: 50$ & $20: 80$ & $50: 50$ & $\mathrm{D}$ & G & $\mathrm{D} \times \mathrm{G}$ \\
\hline Moisture & $73.9 \pm 1.6 \mathrm{Ab}$ & $75.3 \pm 1.5 \mathrm{Aa}$ & $72.3 \pm 0.7 \mathrm{Bb}$ & $74.2 \pm 0.6 \mathrm{Aa}$ & $73.4 \pm 0.6 \mathrm{AB}$ & $72.6 \pm 1.2 \mathrm{~B}$ & 0.040 & 0.002 & 0.001 \\
\hline Lipid & $2.2 \pm 1.0 \mathrm{~B}$ & $2.1 \pm 0.5 \mathrm{~B}$ & $3.8 \pm 1.2 \mathrm{~A}$ & $3.6 \pm 0.7 \mathrm{~A}$ & $3.9 \pm 0.7 \mathrm{~A}$ & $3.1 \pm 1.3 \mathrm{AB}$ & 0.168 & 0.001 & 0.156 \\
\hline Protein & $26.6 \pm 1.1 \mathrm{a}$ & $24.0 \pm 1.4 \mathrm{Bb}$ & $26.2 \pm 1.2$ & $25.3 \pm 0.6 \mathrm{~A}$ & $27.2 \pm 0.8 \mathrm{a}$ & $23.1 \pm 0.6 \mathrm{Bb}$ & 0.003 & 0.253 & 0.002 \\
\hline Ash & $0.8 \pm 0.07 \mathrm{Bb}$ & $1.0 \pm 0.05 \mathrm{Aa}$ & $1.2 \pm 0.05 \mathrm{Aa}$ & $1.0 \pm 0.04 \mathrm{Ab}$ & $0.9 \pm 0.06 \mathrm{Bb}$ & $1.1 \pm 0.09 \mathrm{Aa}$ & 0.001 & 0.002 & 0.001 \\
\hline
\end{tabular}

a, b - means followed by different letters are significantly different by Tukey's test, according to the diet.

A, B - means followed by different letters are significantly different by Tukey's test, according to the genotype.

Table 6 - Composition and relationship between the fatty acids in the meat from Santa Inês (SI), Dorper $\times$ Santa Inês $($ DP $\times$ SI), and undefined breed (UDB) lambs according to the forage:concentrate ratio in the diet

\begin{tabular}{|c|c|c|c|c|c|c|c|c|}
\hline \multirow[b]{2}{*}{ Fatty acid (g/100 g) } & \multicolumn{2}{|c|}{ Forage:concentrate ratio (D) } & \multicolumn{3}{|c|}{ Genotype (G) } & \multicolumn{3}{|c|}{ Significance } \\
\hline & $20: 80$ & $50: 50$ & SI & $\mathrm{DP} \times \mathrm{SI}$ & UDB & $\mathrm{D}$ & G & $\mathrm{D} \times \mathrm{G}$ \\
\hline C14:0 myristic & $1.88 \pm 1.6$ & $2.18 \pm 1.7$ & $2.90 \pm 1.0$ & $2.15 \pm 2.0$ & $0.70 \pm 0.5$ & 0.259 & 0.452 & 0.357 \\
\hline C16:0 palmitic & $15.66 \pm 2.4$ & $14.63 \pm 2.5$ & $16.06 \pm 2.6$ & $14.34 \pm 2.2$ & $15.03 \pm 2.3$ & 0.269 & 0.154 & 0.263 \\
\hline C16:1 palmitoleic & $2.20 \pm 0.5$ & $2.56 \pm 1.0$ & $2.72 \pm 1.1$ & $2.12 \pm 0.6$ & $2.31 \pm 0.5$ & 0.273 & 0.353 & 0.258 \\
\hline C17:0 heptadecanoic & $0.45 \pm 0.1 b$ & $0.60 \pm 0.1 \mathrm{a}$ & $0.45 \pm 0.1 \mathrm{ab}$ & $0.59 \pm 0.1 \mathrm{a}$ & $0.43 \pm 0.0 \mathrm{~b}$ & 0.034 & 0.019 & 0.156 \\
\hline C18:0 stearic & $24.78 \pm 1.8$ & $26.11 \pm 1.9$ & $25.30 \pm 2.5$ & $25.59 \pm 1.9$ & $25.46 \pm 1.4$ & 0.568 & 0.467 & 0.472 \\
\hline C18:1 oleic & $51.45 \pm 2.8$ & $50.23 \pm 3.8$ & $49.20 \pm 3.6$ & $51.36 \pm 3.0$ & $51.95 \pm 2.8$ & 0.371 & 0.378 & 0.254 \\
\hline C18:2 linoleic & $3.77 \pm 1.0$ & $3.93 \pm 1.0$ & $4.01 \pm 1.3$ & $3.80 \pm 0.9$ & $3.72 \pm 0.7$ & 0.159 & 0.153 & 0.025 \\
\hline C18:3 linolenic & $0.68 \pm 0.4$ & $0.82 \pm 0.3$ & $0.91 \pm 0.4$ & $0.79 \pm 0.4$ & $0.58 \pm 0.2$ & 0.464 & 0.752 & 0.566 \\
\hline C20:0 arachidic & $0.96 \pm 0.3 b$ & $1.23 \pm 0.4 \mathrm{a}$ & $1.32 \pm 0.5 \mathrm{a}$ & $1.02 \pm 0.3 \mathrm{ab}$ & $0.95 \pm 0.3 b$ & 0.002 & 0.001 & 0.010 \\
\hline $\mathrm{SFA}^{1}$ & $41.96 \pm 1.6$ & $42.30 \pm 2.5$ & $42.60 \pm 1.9$ & $42.12 \pm 2.0$ & $41.70 \pm 2.3$ & 0.357 & 0.253 & 0.352 \\
\hline MUFA $^{1}$ & $53.65 \pm 2.8$ & $52.62 \pm 3.3$ & $51.65 \pm 3.0$ & $53.48 \pm 2.8$ & $54.26 \pm 3.3$ & 0.571 & 0.778 & 0.567 \\
\hline PUFA $^{1}$ & $4.47 \pm 1.1$ & $4.64 \pm 0.9$ & $4.72 \pm 1.1$ & $4.63 \pm 1.0$ & $4.32 \pm 0.8$ & 0.353 & 0.259 & 0.262 \\
\hline $\mathrm{UFA}^{1}$ & $57.87 \pm 1.8$ & $57.34 \pm 2.0$ & $55.90 \pm 3.1$ & $57.73 \pm 2.2$ & $58.24 \pm 2.2$ & 0.866 & 0.652 & 0.754 \\
\hline MUFA/SFA & $1.28 \pm 0.11$ & $1.26 \pm 0.14$ & $1.23 \pm 0.11$ & $1.28 \pm 0.12$ & $1.31 \pm 0.14$ & 0.558 & 0.278 & 0.465 \\
\hline PUFA/SFA & $0.11 \pm 0.03$ & $0.11 \pm 0.02$ & $0.11 \pm 0.03$ & $0.11 \pm 0.04$ & $0.10 \pm 0.03$ & 0.456 & 0.459 & 0.654 \\
\hline UFA/SFA & $1.38 \pm 0.1$ & $1.33 \pm 0.2$ & $1.29 \pm 0.2$ & $1.38 \pm 0.1$ & $1.40 \pm 0.1$ & 0.559 & 0.758 & 0.558 \\
\hline $\mathrm{DFA}^{2}$ & $82.60 \pm 2.8$ & $82.44 \pm 2.9$ & $80.72 \pm 3.3$ & $83.24 \pm 2.1$ & $83.60 \pm 2.1$ & 0.852 & 0.556 & 0.774 \\
\hline$\omega 6 / \omega 3$ & $0.19 \pm 0.11$ & $0.21 \pm 0.06$ & $0.21 \pm 0.09$ & $0.22 \pm 0.11$ & $0.16 \pm 0.04$ & 0.478 & 0.458 & 0.579 \\
\hline $\mathrm{AI}^{3}$ & $0.30 \pm 0.09$ & $0.33 \pm 0.12$ & $0.37 \pm 0.13$ & $0.31 \pm 0.11$ & $0.27 \pm 0.05$ & 0.259 & 0.152 & 0.261 \\
\hline
\end{tabular}

${ }^{1}$ Sum of saturated fatty acids (SFA), monounsaturated fatty acids (MUFA), polyunsaturated fatty acids (PUFA), and unsaturated fatty acids (UFA)

${ }^{2}$ Desirable fatty acids $=$ MUFA + PUFA + C18: 0 .

${ }^{3}$ Atherogenicity index $=[(\mathrm{C} 12: 0+(4 \times \mathrm{C} 14: 0)+\mathrm{C} 16: 0)] /$ the sum of unsaturated fatty acids.

$\mathrm{a}, \mathrm{b}$ - means followed by different letters are significantly different, as determined using Tukey's test. 
would have a more pronounced hypercholesterolemic effect among the saturated fatty acids. However, the meat from the lambs evaluated in this study showed a considerably reduced percentage of myristic acid in contrast to the high values observed by Díaz et al. (2005) in the meat of sheep produced in Spain, UK, Germany, and Uruguay.

Among the saturated fatty acids, only heptadecanoic $(\mathrm{C} 17: 0)$ and arachidic acids $(\mathrm{C} 20: 0)$ differed $(\mathrm{P}<0.05)$ between the treatments. For $\mathrm{C} 20: 0$, based on the interactions observed, its concentration was higher in the meat from the Santa Inês lambs fed the diet containing the 50:50 forage: concentrate ratio. This behavior would be expected for the other long-chain fatty acids based on the diets provided; however, likely due to the greater variability in the areas of these fatty acids in the chromatograms, no significant differences were observed $(\mathrm{P}>0.05)$.

\section{Discussion}

The Dorper $\times$ Santa Inês lambs were characterized by higher carcass fat levels, followed by the lower percentages of the UDB and Santa Inês lambs, most likely due to the greater precocity of the crossbred Dorper lambs compared with the other genotypes studied (Madruga et al., 2006). According to Furusho-Garcia et al. (2004), crossing Santa Inês lambs with high-meat-producing breeds has been suggested as an important tool for increasing meat production and improving productive efficiency. According to Barros et al. (2005), Dorper $\times$ Santa Inês lambs finished in a feedlot system are an economically viable management practice in the Northeast region of the country; however, in this study, the lambs from this genetic group were not exceptional $(\mathrm{P}>0.05)$ compared with the animals from the other groups surveyed.

Based on a relatively slow $\mathrm{pH}$ reduction in the first 45 min after slaughter (Table 4), an appropriate reduction in the glycolysis rate in the post mortem period was expected. Under normal conditions, the $\mathrm{pH}$ gradually declines after slaughter from values near neutrality in the living animal to 5.5 in the meat (Apple et al., 1995).

The initial $\mathrm{pH}(0 \mathrm{~h})$, the $\mathrm{pH} 45$ min after slaughter and the final $\mathrm{pH}(24 \mathrm{~h})$ did not differ between the genetic groups; however, the $\mathrm{pH}_{0 \mathrm{~h}}$ evaluated for the carcasses of lambs fed diets with the 50:50 forage:concentrate ratio was higher than that of the carcasses of animals fed the 20:80 forage:concentrate ratio. However, it is worth noting that such differences did not induce noticeable changes in the physical and chemical qualities of the meat.

The lower fat concentration in the carcass of the animals fed a high forage level (Table 3 ) more effectively favored thermal energy conduction through the muscle tissues due to lower lipid barriers for heat dissipation (Oliveira et al., 2004), which was reflected in the higher temperatures at the time of evaluation. Furthermore, the meat with higher lipid levels (i.e., meat from Dorper $\times$ Santa Inês, $35.8^{\circ} \mathrm{C}$; and UDB, $35.2{ }^{\circ} \mathrm{C}$ ) was characterized by greater temperature conservation and, therefore, higher temperature upon assessment $45 \mathrm{~min}$ after slaughter (Table 4). Oliveira et al. (2004) reported that the speed of biochemical changes in muscles during the post-mortem period (i.e., glycolysis and subsequent $\mathrm{pH}$ reduction) was faster at higher temperatures. Madruga et al. (2005) reported higher lipid concentrations in the meat from Santa Inês lambs fed diets supplemented with waterweed $(6.93 \mathrm{~g} / 100 \mathrm{~g})$, pineapple stubble $(8.09 \mathrm{~g} / 100 \mathrm{~g})$, and corn silage $(8.38 \mathrm{~g} / 100 \mathrm{~g})$.

The absence of a significant effect of the diet on the lipid concentrations of sheep meat may be possibly due to the intermediate maturation, which has been observed in muscle tissue (Table 5), particularly in the longissimus muscle compared with fat deposits (Atti and Mahouachi, 2009).

Although the diets were isoproteic, the diets with a lower forage percentage may have led to higher synthesis of microbial protein and, consequently, greater muscle tissue production in the lambs, perhaps due to the varying proportions of other compounds, which resulted in different slaughter ages (Misra et al., 2006).

Generally, diets with higher forage contents yield higher acetic acid levels in the rumen environment compared with diets that contain higher concentrate percentages. At the cellular level, once absorbed by the ruminant, this acid is rapidly metabolized into acetyl $\mathrm{CoA}$ and can follow different metabolic pathways, including pathways that contribute to long-chain fatty acid synthesis for body lipids (Van Soest, 1994). These conditions may have favored the differences in the $\mathrm{C} 17: 0$ and $\mathrm{C} 20: 0$ percentages in the meat from lambs fed the different forage:concentrate ratios (Table 6). Values similar to those reported herein were found by Madruga et al. (2006) and Costa et al. (2009) in meat from Santa Inês and Dorper $\times$ Santa Inês lambs.

The forage intake generally reduces the transfer of dietary polyunsaturated fatty acids into ruminant muscle tissue because fiber stimulates ruminal activity and the biohydrogenation process (Lee et al., 2006). However, the reduced diet particle size promoted by the combination of the haying and grinding techniques used in this study likely increased the rate of food passage through the rumen (Bezerra et al., 2004). These conditions decreased biohydrogenation, which favors unsaturated fatty acid deposition in the meat, perhaps explaining the lack of differences $(\mathrm{P}>0.05)$ in the levels of these fatty acids in 
the meat from lambs supplemented with both forage: concentrate ratios $(57.8 \times 57.3 \mathrm{~g} / 100 \mathrm{~g})$.

Generally, diets with high concentrate levels have a lower $\mathrm{pH}$ in the rumen environment and modified microbial flora, with a lower number of protozoa and a higher number of bacteria that produce lactate (Owens et al., 1998), which promotes the accumulation of the C18:2 isomer (trans -10 , cis-12) due to incomplete biohydrogenation. This isomer inhibits the $\Delta 9$-dessaturase enzyme (Baumgard et al., 2001), which inhibits the oleic acid (C18:1 trans 11) desaturation process in the muscle, resulting in its subsequent conversion to linoleic acid (C18:2 cis -9, trans 11), the major conjugated linoleic acid (CLA) isomer that exhibits anticarcinogenic properties. In this study, the percentage of linoleic acid was higher in the meat from Santa Inês lambs fed the diets containing $500 \mathrm{~g} / \mathrm{kg}$ forage compared with the genotypes studied due to the interaction shown in Table 6 .

The issocaloric substitution of saturated fatty acids for polyunsaturated fatty acids in the human diet reduces the total cholesterol and plasma low-density lipoprotein cholesterol (LDL) levels; however, excessive polyunsaturated fatty acid intake also reduces the cholesterol linked to high-density lipoproteins (HDL). Among the fatty acids, $\omega 3$ (C18:3) reduces hepatic triglycerides synthesis by reducing hepatic synthesis of very low-density lipoproteins (VLDL) and may reduce blood viscosity as well as promote greater endothelial relaxation and anti-arrhythmic effects (Sposito et al., 2007).

The percentage of $\mathrm{C} 18: 1$ in the lamb meat ranged from 49.20 to $51.95 \mathrm{~g} / 100 \mathrm{~g}$ of total fatty acids, making it the most representative fatty acid, as confirmed by Costa et al. (2009). According to these authors, monounsaturated fatty acids, mainly C18:1, have the same effect on cholesterolemia without lowering the HDL-c plasma levels and causing lipid oxidation (Sposito et al., 2007), which exemplifies the positive effects of diets with high percentages of these fatty acids.

The saturated fat levels in the meat from the SI and $\mathrm{DP} \times \mathrm{SI}$ lambs represented $42 \mathrm{~g} / 100 \mathrm{~g}$ of the total fatty acids; however, $25 \mathrm{~g} / 100 \mathrm{~g}$ of these fatty acids were C18:0, which is a null effect. Currently, the ideal, beneficial diet for human health includes polyunsaturated/saturated fatty acids at a ratio above 0.4 (Wood et al., 2003), which is necessary to prevent diseases associated with saturated fat intake. The average result $(0.11)$ obtained in this study is below this minimum recommended value, but the high C18:1 levels show a positive aspect on the meat quality of these lambs.

Determining these ratios or proportions have been suggested as a way to assess the risk that food can increase blood cholesterol levels. The meat from the three genetic groups surveyed had a 0.2 $\omega 6: \omega 3$ ratio (Table 6), which is $50 \%$ less than the maximum recommended value (4.0) to eliminate the dietary risk of developing coronary heart diseases (Wood et al., 2003). The percentage of desirable fatty acids (DFA) is determined by the sum of the UFA plus stearic acid, and the atherogenicity index (AI) is defined as the sum of the lauric acid (C12:0), palmitic acid (C16:0), and four times the proportion of myristic acid (C14:0) amounts, divided by the total unsaturated fatty acids. DFA has been suggested as an indicator of dietary risk for cardiovascular disease due to the intake of certain meats. The percentages of DFA (31.5\%) and AI (0.32) were more satisfactory than those obtained by Costa et al. (2009), who investigated the meat from Morada Nova, SI, and SI $\times$ DP lambs fed similar diets.

\section{Conclusions}

Feedlot lamb diets with high concentrate levels favor production of meat with higher lipid levels, particularly for the Dorper $\times$ Santa Inês and undefined-breed genotypes. Regardless of the genotype and diet, the meat lipid profiles, based on the unsaturated fatty acid and desirable fatty acid levels, show that this product is of satisfactory quality for the consumer market.

\section{References}

AOAC - Association of Official Analytical Chemistry. 2000. Official methods of analysis of AOAC International. 19th ed. Washington, D.C.

Apple, J. K.; Dikeman, M. E.; Minton, J. E.; McMurphy, R. M.; Fedde, M. R.; Leith, D. E. and Unruh, J. A. 1995. Effects of restrain and isolation stress and epidural blockade on endocrine and blood metabolite status, muscle glycogen metabolism, and indice of dark-cutting longissimus muscle of sheep. Journal of Animal Science 73:2295-2307.

Atti, N. and Mahouachi, M. 2009. Effects of feeding system and nitrogen source on lamb growth, meat characteristics and fatty acid composition. Meat Science 81:344-348.

Barros, N. N.; Vasconcelos, V. R.; Wander, A. E. and Araújo, M. R. A. 2005. Eficiência bioeconômica de cordeiros $F_{1}$ Dorper $\times$ Santa Inês para produção de carne. Pesquisa Agropecuária Brasileira 40:825-831.

Brasil. Ministério da Agricultura. 1997. Regulamento da inspeção industrial e sanitária de produtos de origem animal. Ministério da Agricultura, Brasília, DF.

Baumgard, L. H.; Sangster, J. K. and Bauman, D. E. 2001. Milk fat synthesis in dairy cows is progressively reduced by increasing supplemental amounts of trans-10,cis-12 conjugated linoleic acid (CLA). Journal of Nutrition 131:1764-1769.

Bezerra, E. S.; Queiroz, A. C.; Bezerra, A. R. G. F.; Pereira, J. C. and Paulino, M. F. 2004. Perfil granulométrico da fibra dietética sobre o tempo médio de retenção e a digestibilidade aparente de dietas para vacas leiteiras. Revista Brasileira de Zootecnia 33:2378-2386. 
Bonamone, A. M. D. and Rundy, S. M. 1988. Effect of dietary stearic acid on plasma cholesterol and lipoprotein levels. The New England Journal of Medicine 318:1244-1248.

Cezar, M. F. and Sousa, W. H. 2007. Carcaças ovinas e caprinas: obtenção, avaliação e classificação. Ed. Agropecuária Tropical, Uberaba.

Chiara, V. L.; Silva, R.; Jorge, R. and Brasil, A. P. 2002. Ácidos graxos trans: doenças cardiovasculares e saúde materno-infantil. Revista de Nutrição 15:341-349.

Costa, R. G.; Batista, A. S. M.; Azevedo, P. S.; Queiroga, R. C. R. E; Madruga, M. S. and Araújo Filho, J. T. 2009. Lipid profile of lamb meat from different genotypes submitted to diets with different energy levels. Revista Brasileira de Zootecnia 38:532-538.

Demirel, G.; Ozpinar, H.; Nazli B. and Keser, O. 2006. Fatty acids of lamb meat from two breeds fed different forage: concentrate ratio. Meat Science 72:229-235.

Díaz, M. T.; Álvarez, I.; De La Fuente, J.; Sanudo, C.; Campo, M. M. and Oliver, M. A. 2005. Fatty acid composition of meat from typical lamb production systems of Spain, United Kingdom, Germany and Uruguay. Meat Science 71:256-263.

Folch, J.; Less, M. and Stanley, S. 1957. A simple method for the isolation and purification of total lipids from animal tissues. Journal Biological Chemistry 226:497-509.

French, P.; O'Riordan, E. G.; Monahan, F. J.; Caffrey, P. J. and Moloney A. P. 2003. Fatty acid composition of intra-muscular triacylglycerols of steers fed autumn grass and concentrates. Livestock Production Science 81:307-317.

Furusho-Garcia, I. F.; Perez, J. R. O.; Bonagurio, S.; Assis, R. M.; Pedreira, B. C. and Souza, X. R. 2004. Desempenho de cordeiros Santa Inês puros e cruzas Santa Inês com Texel, Ile de France e Bergamácia. Revista Brasileira de Zootecnia 33:1591-1603.

Harris, L. F. 1970. Nutrition research technique for domestic and wild animal. v.1. Logan, Utah.

Hartman, L. and Lago, B. C. 1973. A rapid preparation of fatty acid methyl esters from lipids. Laboratory Practice 22:475-477.

Humada, M. J.; Serrano, E.; Sañudo, C. and Rolland, D. C. 2012. Production system and slaughter age effects on intramuscular fatty acids from young Tudanca bulls. Meat Science 90:678-685.

Lee, M. R. F.; Tweed, J. K. S.; Dewhurst, R. J. and Scollan, N. D. 2006. Effect of forage: concentrate ratio on ruminal metabolism and duodenal flow of fatty acids in beef steers. Animal Science 82:31-40.

Lopes, L. S.; Martins, S. R.; Chizzotti, M. L.; Busato, K. C.; Oliveira, I. M.; Machado Neto, O. R.; Paulino, P. V. R.; Lanna, D. P. D. and Ladeira, M. M. 2014. Meat quality and fatty acid profile of Brazilian goats subjected to different nutritional treatments. Meat Science 97:602-608.

Madruga, M. S.; Sousa, W. H.; Rosales, M. D.; Cunha, M. G. G. and Ramos, J. L. F. 2005. Qualidade da carne de cordeiros Santa Inês terminados com diferentes dietas. Revista Brasileira de Zootecnia 34:309-315.
Madruga, M. S.; Araújo, W. O.; Sousa, W. H.; Cezar, M. F.; Galvão, M. S. and Cunha, M. G. G. 2006. Efeito do genótipo e do sexo sobre a composição química e o perfil de ácidos graxos da carne de cordeiros. Revista Brasileira de Zootecnia 35:1838-1844.

Martínez-Cerezo, S.; Sañudo, C.; Panea, B. and Olleta, J. L. 2005. Breed, slaughter weight and ageing time effects on physicochemical characteristics of lamb meat. Meat Science 69:325-333.

Misra, A. K.; Mishra, A. S.; Tripathi, M. K. Chaturvedi, O. H.; Vaithiyanathan, S.; Prasad, R. and Jakhmola, R. C. 2006. Intake, digestion and microbial protein synthesis in sheep on hay supplemented with prickly pear cactus [Opuntia ficus-indica (L.) Mill.] with or without groundnut meal. Small Ruminant Research 63:125-134.

NRC - National Research Council. 2007. Nutrient requirements of sheep. National Academy Press, Washington, D.C.

Oliveira, I.; Silva, T. J. P.; Freitas, M. Q. and Tortelly, R. 2004. Caracterização do processo de rigor mortis em músculos de cordeiros e carneiros da raça Santa Inês e maciez da carne. Acta Scientiae Veterinariae 32:25-31.

Owens, F. N.; Secrist, D. S.; Hill, W. J. and Gill, D. R. 1998. Acidosis in cattle: A review. Journal of Animal Science 76:275-286.

Purchas, R. W.; Davies, A. S. and Abdullah, A. Y. 1991. An objective measure of muscularity: changes with animal growth and differences between genetic lines of Southdown sheep. Meat Science 30:81-94.

Sañudo, C.; Campo, M. M.; Sierra, I.; María, G. A.; Olleta, J. L. and Santolaria, P. 1997. Breed effect on carcass and meat quality of suckling lambs. Meat Science 46:357-365.

Silva Sobrinho, A. G.; Purchas, R. W.; Kadim, I. T. and Yamamoto, S. M. 2005. Características de qualidade da carne de ovinos de diferentes genótipos e idades ao abate. Revista Brasileira de Zootecnia 34:1070-1078.

Sousa, W. H.; Cartaxo, F. Q.; Cezar, M. F.; Gonzaga Neto, S.; Gomes, M. G. and Santos, N. M. 2008. Desempenho e características de carcaça de cordeiros terminados em confinamento com diferentes condições corporais. Revista Brasileira de Saúde e Produção Animal 9:795-803.

Sposito, A. C.; Caramelli, B.; Fonseca, F. A. H.; Bertolami, M. C. and Afiune Neto, A. 2007. IV Diretriz brasileira sobre dislipidemias e prevenção da aterosclerose da Sociedade Brasileira de Cardiologia. Arquivos Brasileiros de Cardiologia 88(Supl. 1):19.

Van Soest, P. J. 1994. Nutrition ecology of the ruminant. 2nd ed. Cornell University Press, Ithaca, NY.

Van Soest, P. J.; Robertson, J. B. and Lewis, B. A. 1991. Symposium: carbohydrate methodology, metabolism, and nutritional implications in dairy cattle. Journal of Dairy Science 74:3583-3597.

Weiss, W. P. 1999. Energy prediction equations for ruminant feeds. p.176-185. In: Proceedings of the 61th Cornell Nutrition Conference Feed Manufactures. Cornell University, Ithaca.

Wood, J. D.; Richardson, R. L.; Nute, G. R.; Fisher, A. V.; Campo, M. M.; Kasapidou, E.; Sheard, P. R. and Enser, M. 2004. Effects of fatty acids on meat quality: a review. Meat Science 66:21-32. 